\title{
Serial Determinations of Blood Lactate in Respiratory Distress Syndrome
}

\author{
J. P. BECA* and J. W. SCOPES \\ From the Neonatal Research Unit, Institute of Child Health (London University), Hammersmith Hospital, London
}

Beca, J. P., and Scopes, J. W. (1972). Archives of Disease in Childhood, 47, 550. Serial determinations of blood lactate in respiratory distress syndrome. Blood lactate was measured 4-hourly in 21 newborn babies with respiratory distress syndrome, of whom 13 survived and 8 died. In general, lactate levels were higher in babies who died than in survivors, but there were inconsistencies which were uninterpretable if only a single estimation were made in a baby. Analysis of serial determinations showed that all patients in whom the lactate level never exceeded $35 \mathrm{mg} / 100 \mathrm{ml}$ survived, and babies with high but falling values also did well. Only those who had rising lactate values, even if initially normal, died.

In most cases a high or normal $\mathrm{P}_{\mathrm{a}} \mathrm{O}_{2}$ was associated with normal or decreasing lactate level; but babies with $\mathrm{P}_{\mathrm{a}} \mathrm{O}_{2}$ below $60 \mathrm{mmHg}$ had often also normal or decreasing lactate levels. Some babies had high and increasing lactate levels despite having normal $\mathrm{P}_{\mathrm{a}} \mathrm{O}_{2}$.

In order to use lactate levels for prognosis in respiratory distress syndrome (RDS) serial determinations are required.

It is concluded that there may be a wide range of hypoxaemia without oxygen deficit in body tissues, so that it is not possible to define a 'lower acceptable $\mathrm{P}_{\mathrm{a}} \mathrm{O}_{2}$ ' which will define adequate tissue oxygenation.

The respiratory distress syndrome (hyaline membrane disease) is an example of a condition where the baby has difficulty in taking up adequate amounts of oxygen and in transporting oxygen to sites where it is needed, so that oxygen therapy is an important and much discussed problem in the care of such babies. Because of risks of producing retrolental fibroplasia or lung damage oxygen therapy must be carefully controlled. The practice at the Hammersmith Hospital is to try to maintain $\mathrm{P}_{\mathrm{a}} \mathrm{O}_{2}$ between 60 and $90 \mathrm{mmHg}$ in aortic blood. The optimum $\mathrm{P}_{\mathrm{a}} \mathrm{O}_{2}$ is very difficult to establish; there is some agreement as to the maximum safe limits (Boston, Geller, and Smith, 1966; Roberton et al., 1968; Scopes, 1970), but there are no wellestablished values for the minimum $\mathrm{P}_{\mathrm{a}} \mathrm{O}_{2}$ levels to achieve acceptable tissue oxygenation (Brumley, 1971; Auld, 1971). The minimum $\mathrm{P}_{\mathrm{a}} \mathrm{O}_{2}$ levels have been experimentally studied by Takano (1968) in dogs and by Vaughan and Eitzman (1969) in puppies. Both authors agree that there is evidence of anaerobic metabolism when the $\mathrm{P}_{\mathrm{a}} \mathrm{O}_{2}$ is below 25-35 mmHg. But even in their normal healthy

\footnotetext{
Received 4 January 1972.

$\star$ World Health Organization Fellow. Present address: Hospital L. Calvo MacKenna, A. Varas 360, Santiago, Chile.
}

animals the $\mathrm{P}_{\mathrm{a}} \mathrm{O}_{2}$ levels at which evidence of anaerobiosis appeared varied greatly.

Tissue oxygenation depends not only on arterial $\mathrm{P}_{\mathrm{a}} \mathrm{O}_{2}$ but also on other factors as haemoglobin concentration, cardiac output, degree of shunts, and peripheral circulation. Clinically, babies are seen who are apparently well and others who are very ill, though having the same $\mathrm{P}_{\mathrm{a}} \mathrm{O}_{2}$. The most rational evaluation of oxygen therapy in the treatment of respiratory distress syndrome (RDS) would be to measure mitochondrial oxygen uptake which is clearly not practicable. Even the measurement and interpretation of tissue $\mathrm{P}_{\mathrm{a}} \mathrm{O}_{2}$ (Rodger et al., 1968) has considerable difficulties. However, measurement of blood lactate might provide an indirect evaluation of tissue oxygenation, because tissue hypoxia produces anaerobic metabolism with a large increase in lactate concentration. This has been shown experimentally by Neill et al. (1969) and Huckabee (1961); in adult circulatory failure by Weil and Afifi (1970); and in intrapartum asphyxia by Derom (1965), Yu et al. (1965), and Daniel, Adamsons, and James (1966).

Another important problem in RDS is that of establishing an early prognosis in order to evaluate different therapeutic regimens. The $\mathrm{P}_{\mathrm{a}} \mathrm{O}_{2}$ achieved 
by a newborn baby breathing $100 \% \quad \mathrm{O}_{2} \quad\left(\mathrm{~N}_{2}\right.$ washout) seems the best prognostic sign available (Boston et al., 1966; Roberton et al., 1968). Other factors such as $p \mathrm{H}$, serum $\mathrm{K}, \mathrm{PCO}_{2}$, and buffer base have been evaluated and scored (Stahlman et al., 1967). Initial blood lactate levels as a prognostic index in RDS were studied by Stahlman et al. (1967) and regarded as not adding more information than $p \mathrm{H}$ alone. Matthieu, Gautier, and Prod'hom (1971) studied blood lactate levels before 3 hours of age and found a significant difference between the values of those babies who died and those who survived from RDS, claiming that lactate measurements were of some prognostic value.

There are reports of lactate levels in cord blood related to birth asphyxia (Payne and Acharya, 1965; Marx and Greene, 1965; Kornacki et al., 1967), in normal babies (Koch and Wendel, 1968; $\mathrm{Yu}$ et al., 1965), and of single determinations in babies with RDS (Stahlman et al., 1967; Matthieu et al., 1971) where the levels were related to the prognosis. There is one report in abstract form
(Wang et al., 1963) of serial determinations of lactic acid in RDS.

Our purpose was to study serially blood lactate levels in newborn babies with RDS, firstly in order to seek evidence of adequate tissue oxygenation in babies who would inevitably have a low $\mathrm{P}_{\mathrm{a}} \mathrm{O}_{2}$ at some stage of their illness, and secondly to assess the prognostic value of these measurements.

\section{Clinical material}

The patients studied were those admitted to the Neonatal Unit at the Hammersmith Hospital with clinical manifestations of RDS defined as having two out of the following three signs at 4 hours of age: grunting, recession, and a respiratory rate over 60 per minute. All had umbilical catheters inserted, for monitoring $p \mathrm{H}$ and blood gas levels, and chest $x$-rays. They were treated according to the usual regimen of the Unit (Scopes, 1971).

In all, 21 patients were studied, 7 born at the Hammersmith Hospital and 14 referred from other hospitals. 13 patients survived and 8 died. Their gestational age, birthweight, sex, type of delivery, result of hyperoxia test, age at the onset of study, and necropsy findings are shown in Table I.

TABLE I

Details of 21 Cases of Respiratory Distress Syndrome (RDS)

\begin{tabular}{|c|c|c|c|c|c|c|c|c|c|}
\hline $\begin{array}{l}\text { Case } \\
\text { No. }\end{array}$ & $\begin{array}{c}\text { Gestational } \\
\text { Age } \\
\text { (wk) }\end{array}$ & $\begin{array}{l}\text { Birth- } \\
\text { weight } \\
\text { (g) }\end{array}$ & Sex & Delivery & $\begin{array}{c}\text { Birth } \\
\text { Asphyxia }\end{array}$ & $\underset{\underset{(\mathrm{mmHg})}{\mathrm{N}_{2}}}{\text { Washout } \mathrm{P}_{\mathrm{a}} \mathrm{O}_{2}}$ & $p H$ & $\begin{array}{l}\text { Age at Onset } \\
\text { of Study } \\
\text { (hr) }\end{array}$ & Other Diagnosis or Necropsy \\
\hline Survived & & & & & & & & & \\
\hline 2 & 30 & 1190 & $\mathbf{F}$ & Vertex & Yes & 143 & $7 \cdot 18$ & 9 & $\begin{array}{l}\text { Systemic infection (blood cul- } \\
\text { ture positive) }\end{array}$ \\
\hline 3 & 33 & 1990 & $\mathbf{M}$ & Vertex & No & 一 & - & 19 & Persistent ductus arteriosus \\
\hline 5 & 27 & 1060 & M & Vertex & No & 121 & $7 \cdot 30$ & 13 & \\
\hline 7 & 34 & 1980 & $M$ & Vertex & No & 153 & $7 \cdot 26$ & 6 & \\
\hline 12 & 34 & 1760 & F & $\begin{array}{l}\text { Vertex } \\
\text { Forceps }\end{array}$ & No & - & - & 10 & $\begin{array}{l}\text { Subarachnoid haemorrhage; } \\
\text { apnoeic attacks }\end{array}$ \\
\hline 13 & 34 & 2070 & $\mathbf{F}$ & Breech & No & 173 & $7 \cdot 34$ & 4 & \\
\hline 14 & 35 & 2200 & $\mathbf{F}$ & LSCS & Yes & 169 & $7 \cdot 30$ & 7 & \\
\hline 15 & 33 & 1780 & $\mathbf{M}$ & Vertex & Yes & 44 & $7 \cdot 33$ & 9 & Apnoeic attacks \\
\hline 17 & 33 & 2000 & $\mathbf{F}$ & Vertex & Yes & 91 & $7 \cdot 30$ & 6 & Cardiac arrests \\
\hline 18 & 32 & 1580 & $\mathbf{M}$ & Vertex & Yes & 143 & $7 \cdot 37$ & 4 & Pneumonia; apnoeic attacks \\
\hline 19 & 36 & 2580 & $\mathbf{F}$ & Vertex & No & - & 一 & 7 & \\
\hline \multicolumn{10}{|l|}{ Died } \\
\hline 1 & 30 & 1320 & $\mathrm{~F}$ & Vertex & No & 54 & $7 \cdot 05$ & $5 \frac{1}{2}$ & Pneumothorax; IVH; HMD \\
\hline 4 & 31 & 1060 & M & $\begin{array}{l}\text { Vertex } \\
\text { Forceps }\end{array}$ & No & 206 & $7 \cdot 23$ & $5 \frac{1}{2}$ & $\begin{array}{l}\text { Small-for-dates; thrombocyto- } \\
\text { penia; subarachnoid haemor- } \\
\text { rhage; HMD }\end{array}$ \\
\hline 6 & 27 & 980 & M & Vertex & Yes & 一 & - & 12 & Subdural haemorrhage; HMD \\
\hline 8 & 26 & 800 & $\mathbf{F}$ & Vertex & Yes & 一 & - & 19 & $\begin{array}{l}\text { IVH; tracheal and lung } \\
\text { haemorrhages }\end{array}$ \\
\hline 9 & 36 & 2600 & $\mathbf{F}$ & Vertex & No & 54 & $7 \cdot 07$ & $4 \frac{1}{2}$ & $\begin{array}{l}\text { Subdural and subarachnoid } \\
\text { haemorrhages; HMD }\end{array}$ \\
\hline 10 & 37 & 2120 & $\mathbf{M}$ & Vertex & Yes & 128 & $7 \cdot 02$ & 6 & $\begin{array}{l}\text { Small-for-dates; multiple } \\
\text { congenital abnormalities }\end{array}$ \\
\hline 11 & 33 & 1760 & $\mathbf{F}$ & Breech & No & 32 & $7 \cdot 08$ & 4 & $\begin{array}{l}\text { Subarachnoid haemorrhage; } \\
\text { IVH; HMD }\end{array}$ \\
\hline 16 & 35 & 2250 & $M$ & LSCS & Yes & 102 & $7 \cdot 10$ & 6 & $\begin{array}{l}\text { Coagulation defect; intracranial, } \\
\text { lung, and gastrointestinal } \\
\text { haemorrhages; HMD }\end{array}$ \\
\hline
\end{tabular}

IVH = intraventricular haemorrhage. $\quad$ HMD $=$ hyaline membrane disease. $\quad$ LSCS = lower segment caesarean section. 


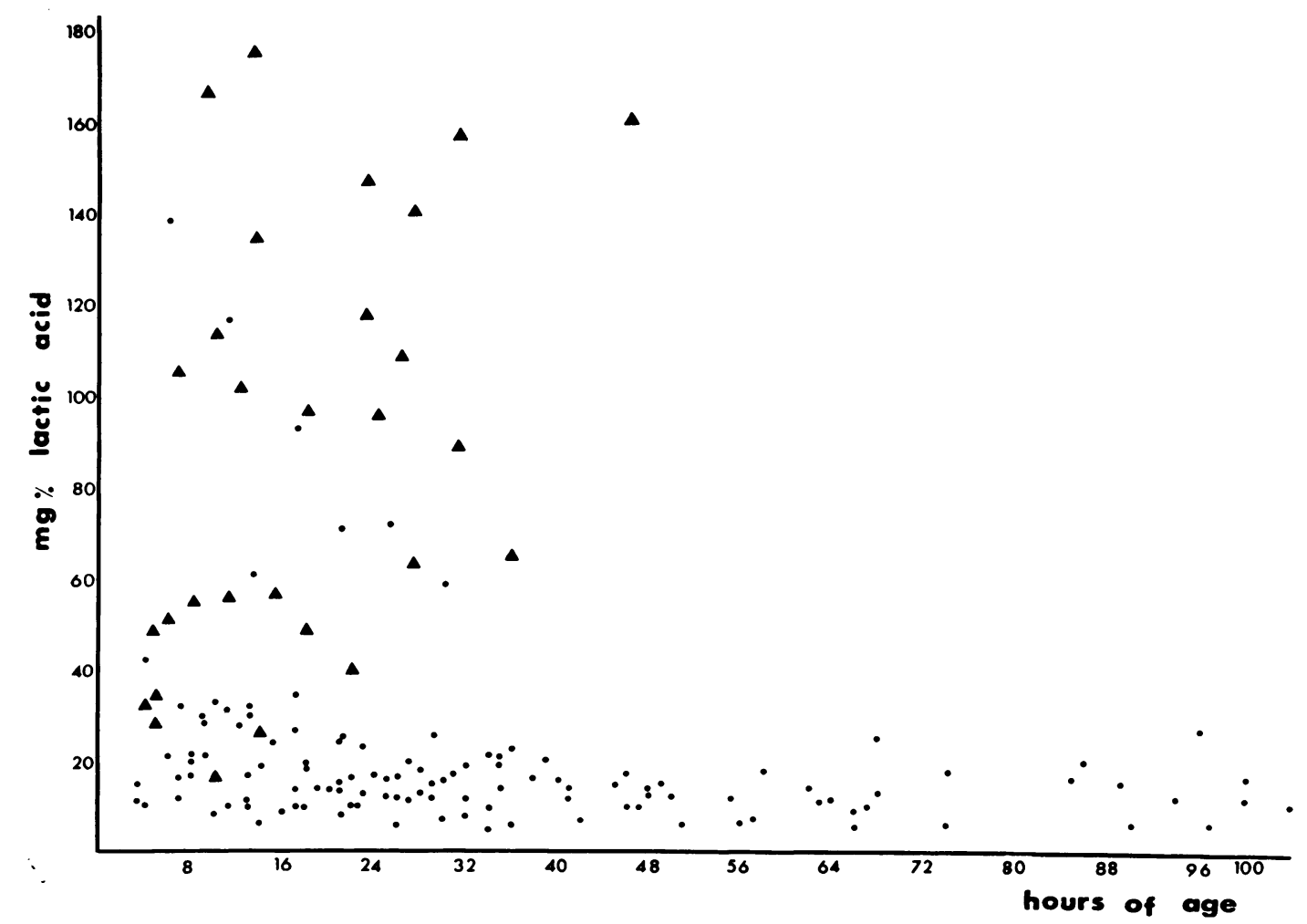

FIG. 1.-Scattergram of lactate measurements related to postnatal age of patients. who survived.

\section{Methods}

In all patients routine clinical observations were recorded and blood sugar, arterial $p H$, arterial blood gases, and blood lactate were measured 4-hourly. Blood sugar was estimated using Dextrostix (Chantler, Baum, and Norman, 1967). Arterial $p \mathrm{H}$ and blood gases were measured with an IL $p \mathrm{H}$ and blood gas analyser 313.

When $0.3 \mathrm{ml}$ blood was withdrawn from the umbilical arterial catheter for $p \mathrm{H}$ and blood gases determination, an extra $0.2 \mathrm{ml}$ was taken for lactate measurement. This sample was immediately deproteinized with $0 \cdot 2$ $\mathrm{ml} 0.6 \mathrm{~N}$ perchloric acid and the supernatant kept at $4{ }^{\circ} \mathrm{C}$. Lactate was measured within the next 24 to 48 hours using the Boehringer modification of the Hohorst enzymatic method (Hohorst, 1957, 1963). A calibration line was drawn from standards on each day and optical densities read at a wavelength of $366 \mathrm{~m} \mu$. The standard deviation of the measurement was \pm 0.48 $\mathrm{mg} / 100 \mathrm{ml}$ at a concentration of $33 \mathrm{mg} / 100 \mathrm{ml}$ and $\pm 0.94 \mathrm{mg} / 100 \mathrm{ml}$ at a concentration of $112 \mathrm{mg} / 100 \mathrm{ml}$.

In these 21 patients there were 150 determinations of lactate levels, with a minimum of 2 and a maximum of 14 in any single baby. 


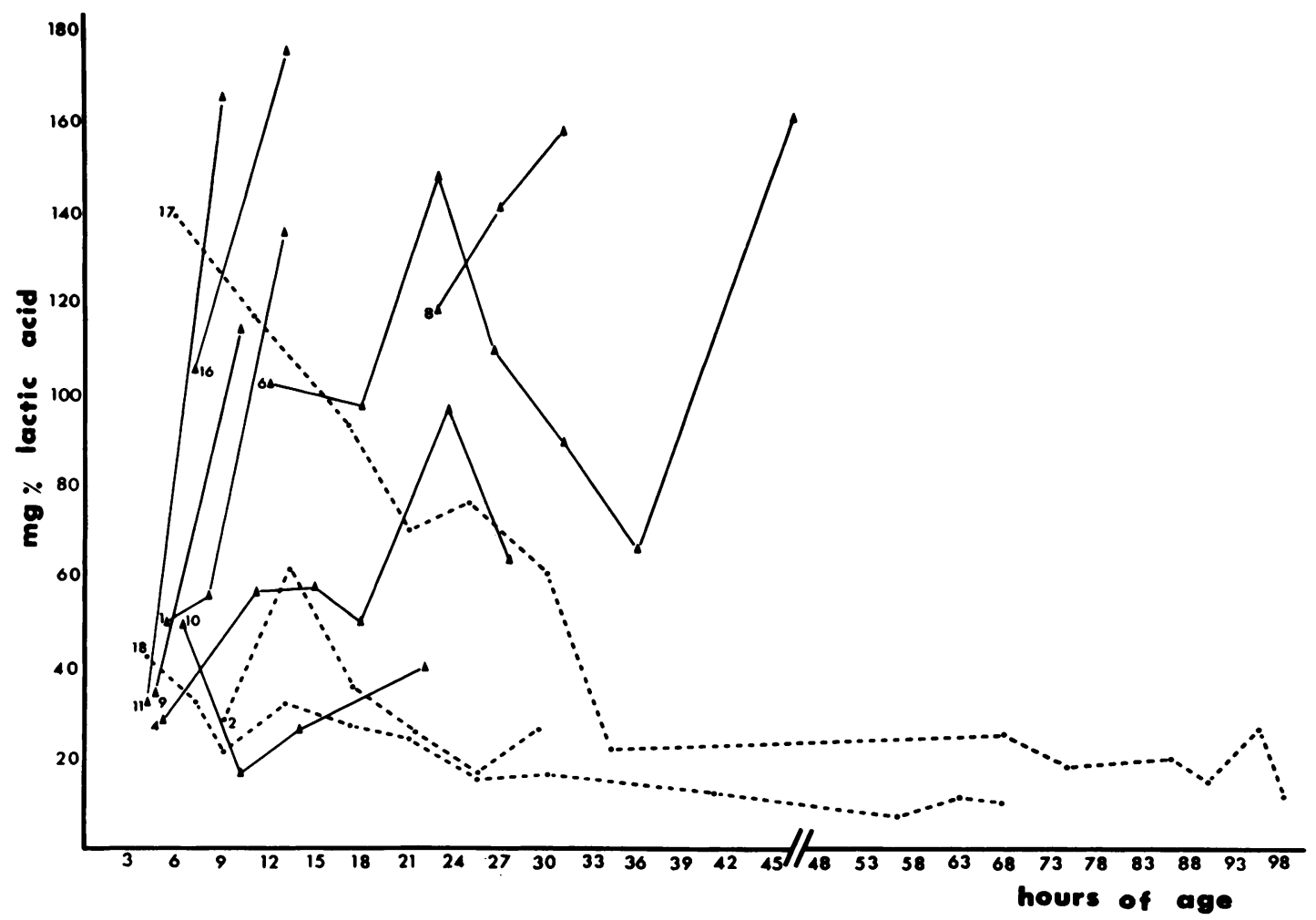

Fig. 2.-Lactate curves in babies who at any stage had blood lactate higher than 35 mg/100 ml. The number at the beginning of each curve is the case number, see Table I. ( $\Delta-\Delta) 8$ cases who died; (...) 3 cases who survived.

treatment, and in whom it was impossible to achieve an acceptable $\mathrm{P}_{\mathrm{a}} \mathrm{O}_{2}$. In all these three babies blood lactate levels had an extremely steeply rising curve, even though initially less than 35 $\mathrm{mg} / 100 \mathrm{ml}$ in Cases 9 and 11 . All died before 14 hours of age and had hyaline membrane disease (HMD) and intracranial haemorrhage at necropsy.

Cases 8 and 16 were preterm babies with severe birth asphyxia who had as their main clinical problems apnoeic attacks and haemorrhages from different sites. Both were extremely acidotic and required the use of a ventilator because of repeated apnoeic episodes. $\quad \mathrm{P}_{\mathrm{a}} \mathrm{O}_{2}$ in Case 8 was between 52 and $67 \mathrm{mmHg}$. Their lactate levels were very high initially and continued to rise until their deaths at 32 and 20 hours of age, respectively. At necropsy there were haemorrhages in the respiratory tract and lungs in Case 8 , intracranial bleeding in both, and in Case 16 also gastrointestinal haemorrhage. Though both patients had clinical RDS, hyaline membranes were not found at necropsy in Case 8.
Cases 4 and 6 had rising blood lactate levels though in each there was a period of temporary fall. Case 4 was a preterm and small-for-dates baby with severe RDS; his lactate concentration was below $35 \mathrm{mg} / 100 \mathrm{ml}$ initially and increased progressively up to $96 \mathrm{mg} / 100 \mathrm{ml}$ at 23 hours. At 26 hours he received a blood transfusion and his blood lactate fell to $65 \mathrm{mg} / 100 \mathrm{ml}$ one hour later; this was not followed by clinical improvement and the baby died at 30 hours of age. Case 6 was a preterm baby with severe RDS who had very low blood gases during the hyperoxia test, was severely acidotic, and required the use of a ventilator during the whole period of study. His $\mathrm{P}_{\mathrm{a}} \mathrm{O}_{2}$, initially low (range 14 to $49 \mathrm{mmHg}$ ), became satisfactory (range 57 to $82 \mathrm{mmHg}$ ) between 23 and 36 hours age and deteriorated thereafter until his death at $\mathbf{4 7}$ hours. His blood lactate value was initially very high, decreased somewhat during the period of acceptable $\mathrm{P}_{2} \mathrm{O}_{2}$ and then increased again. The main necropsy finding was HMD in these two cases. 
Case 10 was a preterm and small-for-dates baby who had multiple congenital abnormalitieshypoplastic lungs, thoracic kyphosis with defect in vertebral bodies T 6 and 7, large enterogenous cyst in the abdomen, small enterogenous cyst in posterior mediastinum with extension into the vertebral canal, and undescended testes. Besides all these problems he had clinical RDS and died at 23 hours of age. His lactate level was initially 51 $\mathrm{mg} / 100 \mathrm{ml}$, fell to $16 \mathrm{mg}$, and then rose progressively up to $40 \mathrm{mg}$. His $\mathrm{P}_{\mathrm{a}} \mathrm{O}_{2}$ was over $100 \mathrm{mmHg}$ during the period of decreasing lactate and between 36 and $40 \mathrm{mmHg}$ after this. This was the only baby in the study where lactate level fell from above to below $35 \mathrm{mg} / 100 \mathrm{ml}$ and who died. Necropsy examination showed the congenital abnormalities but no HMD.

Cases 2,17 , and 18 were survivors who at some stage had a lactate concentration higher than 35 $\mathrm{mg} / 100 \mathrm{ml}$. Case 18 had an initial lactate of 42 $\mathrm{mg}$ at 4 hours age, having had severe birth asphyxia and apnoeic episodes before this age. Lactate decreased after this initial measurement, despite severe respiratory distress that required the use of a ventilator and high concentrations of $\mathrm{O}_{2}$. Even with this therapy his $\mathrm{P}_{\mathrm{a}} \mathrm{O}_{2}$ was often below $60 \mathrm{mmHg}$. Case 2 had an increase in blood lactate between 9 and 13 hours of age reaching a concentration of $61 \mathrm{mg} / 100 \mathrm{ml}$ after three prolonged apnoeic attacks. After this temporary increase, levels of lactate fell and he recovered. Case 17 was exceptional, as he had the highest initial lactate level $(139 \mathrm{mg} / 100 \mathrm{ml})$ in the series and yet survived. Before this measurement made at 6 hours of age the baby had had 'terminal birth asphyxia' (Gupta and Tizard, 1967), two prolonged apnoeic episodes, and at age 4 hours a cardiac arrest; he required artificial ventilation from 9 hours to 10 days of age and finally recovered. Lactate levels fell continuously after this exceptionally high initial value.

In most cases a high or normal $\mathrm{P}_{\mathrm{a}} \mathrm{O}_{2}$ coincided with lactate levels that were either normal or decreasing. When however $\mathrm{P}_{\mathrm{a}} \mathrm{O}_{2}$ was less than $60 \mathrm{mmHg}$, that is within the range generally quoted as meaning unacceptably hypoxaemic, lactate levels were often also normal or decreasing. All but one child (Case 6) in whom this set of circumstances arose recovered and survived. Thus, either falling or normal lactate levels gave evidence of adequate tissue oxygenation despite the low $\mathrm{P}_{\mathrm{a}} \mathrm{O}_{2}$.

For example Case 3 (Fig. 3) was a very ill baby who despite inspired oxygen concentration of near $100 \%$ had $\mathrm{P}_{\mathrm{a}} \mathrm{O}_{2}$ between 25 and $40 \mathrm{mmHg}$ in the first 60 hours. None the less the lactate levels remained stable between 14 and $21 \mathrm{mg} / 100 \mathrm{ml}$ and the child survived. In Case 17 (Fig. 3) there was a dramatic fall in lactate from 139 to $21 \mathrm{mg} /$ $100 \mathrm{ml}$ during a period in which the $\mathrm{P}_{\mathrm{a}} \mathrm{O}_{2}$ was mostly below $60 \mathrm{mmHg}$, and she recovered.

The opposite of these circumstances was finding a rising lactate level despite acceptable $\mathrm{P}_{\mathrm{a}} \mathrm{O}_{2}$ measurements. In Case 16 (Fig. 2) high and rising lactate levels occurred despite $\mathrm{P}_{\mathrm{a}} \mathrm{O}_{2}$ of over $100 \mathrm{mmHg}$ and the child rapidly succumbed. In Case 8 (Fig. 2) $\mathrm{P}_{\mathrm{a}} \mathrm{O}_{2}$ measurements were marginally low (52 to $67 \mathrm{mmHg}$ ) but lactate levels rose sharply and again the baby died.

\section{Discussion}

Normal values of blood lactate were not determined in this study as we did not consider it justifiable to insert catheters in healthy babies, but these have been established by others. Koch and Wendel (1968) established lactate values for normal newborn babies, studying systematically 79 infants from birth to 7 days of age, using umbilical arterial blood and using the same method we used. Their normal values are shown in Table II. Lactate

\section{TABLE II}

Mean (and Range) of Normal Blood Lactate Concentration in Newborn Infants (Koch and Wendel, 1968)

\begin{tabular}{l|c|c}
\hline \multicolumn{1}{c|}{ Age } & $\mathrm{mg} / 100 \mathrm{ml}$ & $\mathrm{mEq} / \mathrm{l}$. \\
\hline Birth (cord) & $24 \cdot 3(13 \cdot 5-41 \cdot 0)$ & $2 \cdot 7(1 \cdot 5-4 \cdot 5)$ \\
$5-10 \mathrm{~min}$ & $34 \cdot 2(23 \cdot 4-42 \cdot 3)$ & $3 \cdot 8(2 \cdot 6-4 \cdot 7)$ \\
$30 \mathrm{~min}$ & $19 \cdot 8(10 \cdot 8-38 \cdot 7)$ & $2 \cdot 2(1 \cdot 2-4 \cdot 3)$ \\
$60 \mathrm{~min}$ & $14 \cdot 4(8 \cdot 1-24 \cdot 3)$ & $1 \cdot 6(0 \cdot 9-2 \cdot 7)$ \\
$5 \mathrm{hr}$ & $11 \cdot 7(8 \cdot 1-18 \cdot 0)$ & $1 \cdot 3(0 \cdot 9-2 \cdot 0)$ \\
$24 \mathrm{hr}$ & $9 \cdot 0(7 \cdot 2-10 \cdot 8)$ & $1 \cdot 0(0 \cdot 8-1 \cdot 2)$ \\
$7 \mathrm{dy}$ & $8 \cdot 1(4 \cdot 5-12 \cdot 6)$ & $0 \cdot 9(0 \cdot 5-1 \cdot 4)$ \\
\hline
\end{tabular}

levels in healthy preterm infants were studied by Yu et al. (1965) and did not differ significantly from those of term infants. It is obvious from these two studies that measurements made before 3 hours of age would reflect what had happened at birth rather than what the situation might be at the time of sampling. This is in keeping with the fact that the mean life of lactate in newborn babies is longer than 60 minutes (Ciampolini and Franchini, 1966).

Blood lactate concentration may be increased by causes other than tissue hypoxia, mainly exercise, hypocapnia, or liver dysfunction. When tissue hypoxia occurs, the lactate dehydrogenase system shifts towards a more reduced state, and lactic 


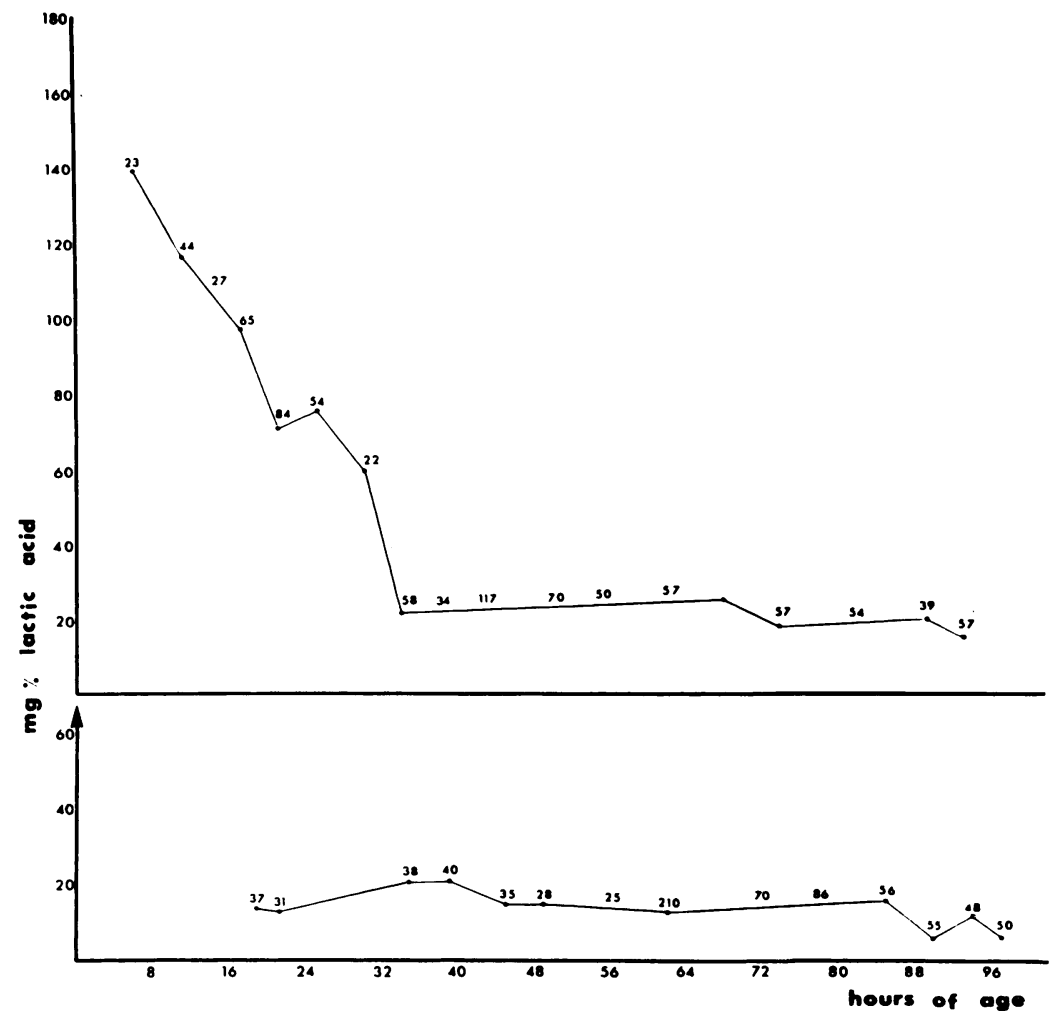

Fig. 3. - Lactate curves in 2 cases where the pattern was favourable, falling (Case 17, top curve), or consistently normal (Case 3 , lower curve). Numbers give $P_{\mathrm{a}} o_{2}$ measurements in $\mathrm{mmHg}$ at each age.

acid production exceeds that of pyruvic acid, producing an increase in the lactate/pyruvate ratio $(\mathrm{L} / \mathrm{P})$. This led Huckabee (1958a) to propose the calculation of excess lactate (XL) as an unequivocal sign of anaerobic metabolism. However the value of $\mathrm{XL}$ as an invariable indicator of tissue hypoxia has been questioned (Olson, 1963; Alpert, 1965). $\mathrm{L} / \mathrm{P}$ and $\mathrm{XL}$ also vary with hypocapnia (Cain, 1968) and lacate levels alone correlate with signs of tissue oxygen deficit in the same way as XL or L/P (Daniel et al., 1966; Weil and Afifi, 1970). $\mathrm{XL}$ is a measurement requiring previous determinations of lactate and pyruvate levels in the nonhypoxic state and is not feasible in clinical situations. Pyruvate determinations require undesirably large samples of blood for a systematic study in the newborn. Therefore we did not measure pyruvic acid and we interpret the large increases in blood lactate found as qualitative but not quantitative evidence of tissue hypoxia. This interpretation has been established experimentally (Huckabee, 1958b; Takano, 1970), and in several clinical condi- tions (Weil and Afifi, 1970), including some cases of RDS (Wang et al., 1963; Payne and Acharya, 1965).

The other major causes of increased lactate are exercise, hypocapnia, and liver dysfunction. Muscular activity of patients studied in this series was observed and recorded and no correlation was found between high lactate level and hyperactivity; on the contrary those babies with high lactate concentrations were usually the very sick and inactive babies. The rise in lactate that occurs with hypocapnia is small compared with the levels described here, and we found no correlation between high lactate levels and the occasionally low $\mathrm{PCO}_{2}$. We did no liver function tests in these babies; it is probable that a baby who has tissue hypoxia has a degree of liver dysfunction which would in part explain the lactate rise observed, an added reason for not drawing quantitative conclusions from these results.

The relation between $p \mathrm{H}$ and lactate concentration is difficult to establish. A high blood lactate 
is usually accompanied by a low $p \mathrm{H}$. Alkali therapy corrects $p \mathrm{H}$ but does not necessarily change the lactate concentration. Therefore there might be, as we found on several occasions, high lactate concentration coincident with a normal $p \mathrm{H}$, or a normai lactate in the presence of low $p H$. Increasing lactate levels were not accompanied by decreasing $p \mathrm{H}$ curves for the latter was modified by alkali therapy, and therefore $p \mathrm{H}$ curves did not have the prognostic value that lactate curves had. Nevertheless lactate is one of the determinant factors of a low $p \mathrm{H}$ in metabolic acidosis, and therefore much but not all the information obtainable from its measurements is also obtained by monitoring $p \mathrm{H}$, especially in situations where alkali therapy is not needed.

No attempt was made in this study to standardize the age at which the initial measurement of lactate was made, as umbilical arterial catheters were inserted for clinical reasons at the age patients entered our unit. It was however clear that initial lactate levels were as a whole lower in survivors from RDS than in those who died, but variations were too large in each group to establish any conclusions. Stahlman et al. (1967) found the same in their series and left lactate out of their proposed score for prognostication in RDS. Gautier (1971) has recently reported high lactate measurements to be correlated with low Apgar score and bad prognosis in RDS. These measurements were done before 3 hours of age, when they probably say more about the past than about the future.

Our results show that a single measurement of blood lactate is of little prognostic value, only serial measurements to show either an increasing or a decreasing curve being helpful in establishing a good or a bad prognosis in RDS. An early prognosis cannot therefore be established on this basis. The value of $\mathrm{N}_{2}$ washout as an early and practical test was once more corroborated by our results, as can be seen in Table I.

These results give support to the concept that there may be a wide range of hypoxaemia not associated with deficiency of oxygen in body tissues. This makes it impossible to define a 'minimum acceptable $\mathrm{P}_{\mathrm{a}} \mathrm{O}_{2}$ ', for a different figure would apply for each individual baby and for each stage in his disease. Thus a high and increasing lactate concentration gives better evidence of inadequate tissue oxygenation than any arbitrary level of 'low' $\mathrm{P}_{\mathrm{a}} \mathrm{O}_{2}$. A baby with a $\mathrm{P}_{\mathrm{a}} \mathrm{O}_{2}$ below $60 \mathrm{mmHg}$ and a normal or decreasing lactate level has no evidence of lack of oxygen and should not be subjected to the known risks of increasing his ambient oxygen, to achieve an 'acceptable' $\mathrm{P}_{\mathrm{a}} \mathrm{O}_{2}$ of more than $60 \mathrm{mmHg}$.

In the reverse situation, there may be a failure in oxygen transport to the tissues though the $\mathrm{P}_{\mathrm{a}} \mathrm{O}_{2}$ is within the accepted normal range. This situation was evident in two of our patients. Therefore, a rising blood lactate level, even in the presence of normal $\mathrm{P}_{\mathrm{a}} \mathrm{O}_{2}$, means that the baby needs further support, either by increasing ambient inspired oxygen using continuous airway pressure or by supporting circulation.

We conclude that in RDS systematic measurements of blood lactate evaluate tissue oxygenation better than do $\mathrm{P}_{\mathrm{a}} \mathrm{O}_{2}$ measurements. Lactate levels may provide useful information for therapy, indicating whether a baby needs to have his inspired oxygen increased or his circulation supported, and they give some prognostic information.

We are grateful to the World Health Organization, the Wellcome Foundation, and the Trustees of the Sir William Coxen Trust Fund for financial support during the study period; and to Professor J. P. M. Tizard for advice.

\section{REFERENCES}

Alpert, N. R. (1965). Lactate production and removal and the regulation of metabolism. Annals of the New York Academy of Sciences, 119, 995.

Auld, P. A. M. (1971). Oxygen therapy for premature infants fournal of Pediatrics, 78, 705.

Boston, R. W., Geller, F., and Smith, C. A. (1966). Arterial blood gas tensions and acid-base balance in the management of the respiratory distress syndrome. Fournal of Pediatrics, 68, 74.

Brumley, G. W. (1971). The critically ill child: the respiratory distress syndrome of the newborn. Pediatrics, 47, 758.

Cain, S. M. (1968). Effect of $\mathrm{PcO}_{2}$ on the relation of lactate and excess lactate to $\mathrm{O}_{2}$ deficit. American fournal of Physiology, 214, 1322.

Chantler, C., Baum, J. D., and Norman, D. A. (1967). Dextrostix in the diagnosis of neonatal hypoglycaemia. Lancet, 2, 1395.

Ciampolini, M., and Franchini, F. (1966). Modifications of lactate metabolism in the first month of life: intravenous loading test of DL-lactate in premature newborn infants. Annales Paediatrici, 207, 335.

Daniel, S. S., Adamsons, K., Jr., and James, L. S. (1966). Lactate and pyruvate as an index of prenatal oxygen deprivation. Pediatrics, 37, 942.

Derom, R. (1965). Anaerobic metabolism in the human fetus II. The twin delivery. American fournal of Obstetrics and Gynecology, 82, 555.

Gautier, E. (1970). Lactic acidosis in infancy. Helvetica Medica Acta, 35, 423.

Gupta, J. M., and Tizard, J. P. M. (1967). The sequence of events in neonatal apnoea. Lancet, 2, 55.

Hohorst, H. J. (1957). Enzymatische Bestimmung von $\mathbf{L}(+)$ Milchsäure. Biochemische Zeitschrift, 328, 509.

Hohorst, H. J. (1963). L (+) lactate determination with LDH and DPN. In Methods of Enzymatic Analysis, p. 266. Ed. by H. U. Bergmeyer. Academic Press, New York and London.

Huckabee, W. E. (1958a). Relationships of pyruvate and lactate during anaerobic metabolism. I. Effects of infusion of pyruvate or glucose and of hyperventilation. Fournal of Clinical Investigation, 37, 244.

Huckabee, W. E. (1958b). Relationships of pyruvate and lactate during anaerobic metabolism. III. Effect of breathing lowoxygen gases. Fournal of Clinical Investigation, 37, 264. 
Huckabee, W. E. (1961). Abnormal resting blood lactate. I. The significance of hyperlactatemia in hospitalized patients. American fournal of Medicine, 30, 833.

Koch, G., and Wendel, H. (1968). Adjustment of arterial blood gases and acid base balance in the normal newborn infant during the first week of life. Biology of the Neonate, 12, 136.

Kornacki, Z., Biczysko, R., Obara, M., and Wasicki, A. (1967). The lactates to pyruvates ratio in umbilical blood samples from healthy and asphyxiated newborn infants. (Polish.) Ginekologia Polska, 38, 969.

Marx, G. F., and Greene, N. M. (1965). Lactate/pyruvate ratio of umbilical vein blood. American fournal of Obstetrics and Gynecology, 92, 548.

Matthieu, J. M., Gautier, E., and Prod'hom, L. S. (1971). La lactacidémie: reflet de l'asphyxie périnatale et valeur de pronostic. (Abst.) Helvetica Paediatrica Acta, Suppl. 25, 16.

Neill, W. A., Jensen, P. E., Rich, G. B., and Werschkul, J. D. (1969). Effect of decreased $\mathrm{O}_{2}$ supply to tissue on the lactate: pyruvate ratio in blood. Fournal of Clinical Investigation, 48, 1862.

Olson, R. E. (1963). 'Excess lactate' and anaerobiosis. Annals of Internal Medicine, 59, 960.

Payne, W. W., and Acharya, P. T. (1965). The effect of abnormal birth on blood chemistry during the first 48 hours of life. Archives of Disease in Childhood, 40, 436

Roberton, N. R. C., Gupta, J. M., Dahlenburg, G. W., and Tizard, J. P. M. (1968). Oxygen therapy in the newborn. Lancet, 1, 1323.

Rodger, J. C., Kerr, M. M., Richards, I. D. G., and Hutchison, J. H. (1968). Measurements of oxygen tension in subcutaneous tissue of newborn infants under normobaric and hyperbaric conditions. Lancet, 2, 232.
Scopes, J. W. (1970). Idiopathic respiratory distress syndrome. British Fournal of Hospital Medicine, 3, 579.

Scopes, J. W. (1971). Respiratory distress syndrome. In Recent Advances in Paediatrics, 4th ed., p. 87. Ed. by D. Gairdner and D. Hull. Churchill, London.

Stahlman, M. T., Battersby, E. J., Shepard, F. M., and Blankenship, W. J. (1967). Prognosis in hyaline membrane disease: use of a linear-discriminant. New England fournal of Medicine, 276, 303.

Takano, N. (1968). Role of hypocapnia in the blood lactate accumulation during acute hypoxia. Respiration Physiology, 4, 32.

Takano, N. (1970). Effect of $\mathrm{CO}_{2}$ on $\mathrm{O}_{2}$ transport, $\mathrm{O}_{2}$ uptake and blood lactate in hypoxia of anesthetized dog. Respiration Physiology, 10, 38.

Vaughan, O., and Eitzman, D. V. (1969). Hypoxia and lactate in the newborn puppy. Biology of the Neonate, 14, 42.

Wang, S. C. C., Levison, H., Muirhead, D. M., Boston, R. W., and Smith, C. A. (1963). Relationship of blood lactate to acidosis and hypoxia in respiratory distress syndrome. (Abst.) Fournal of Pediatrics, 63, 732.

Weil, M. H., and Afifi, A. A. (1970). Experimental and clinical studies on lactate and pyruvate as indicators of the severity of acute circulatory failure (shock). Circulation, 41, 989.

Yu, J., Payne, W. W., Ifekwunigwe, A., and Stevens, J. (1965). Biochemical status of healthy premature infants in the first 48 hours of life. Archives of Disease in Childhood, 40, 516.

Correspondence to Dr. J. W. Scopes, Neonatal Research Unit, Institute of Child Health, Hammersmith Hospital, Du Cane Road, London W.12. 